\title{
Malignant mammary tumor in female dogs: environmental contaminants
}

\author{
Fábio HE Andrade ${ }^{1}$, Fernanda C Figueiroa ${ }^{2}$, Paulo RO Bersano ${ }^{2}$, Denise Z Bissacot ${ }^{3}$, Noeme S Rocha ${ }^{2 *}$
}

\begin{abstract}
Mammary tumors of female dogs have greatly increased in recent years, thus demanding rapid diagnosis and effective treatment in order to determine the animal survival. There is considerable scientific interest in the possible role of environmental contaminants in the etiology of mammary tumors, specifically in relation to synthetic chemical substances released into the environment to which living beings are either directly or indirectly exposed. In this study, the presence of pyrethroid insecticide was observed in adjacent adipose tissue of canine mammary tumor. High Precision Liquid Chromatography - HPLC was adapted to detect and identify environmental contaminants in adipose tissue adjacent to malignant mammary tumor in nine female dogs, without predilection for breed or age. After surgery, masses were carefully examined for malignant neoplastic lesions. Five grams of adipose tissue adjacent to the tumor were collected to detect of environmental contaminants. The identified pyrethroids were allethrin, cyhalothrin, cypermethrin, deltamethrin and tetramethrin, with a contamination level of 33.3\%.

Histopathology demonstrated six female dogs (66.7\%) as having complex carcinoma and three (33.3\%) with simple carcinoma. From these tumors, seven (77.8\%) presented aggressiveness degree III and two (22.2\%) degree I. Five tumors were positive for estrogen receptors in immunohistochemical analysis. The contamination level was observed in more aggressive tumors. This was the first report in which the level of environmental contaminants could be detected in adipose tissue of female dogs with malignant mammary tumor, by HPLC. Results suggest the possible involvement of pyrethroid in the canine mammary tumor carcinogenesis. Hence, the dog may be used as a sentinel animal for human breast cancer, since human beings share the same environment and basically have the same eating habits.
\end{abstract}

\section{Introduction}

Currently, mammary tumors represent $50 \%$ of all neoplasms that afflict female dogs [1,2], and from these tumors 41 to $53 \%$ are of malignant character [3-5]. Epidemiological and clinical characteristics as well as biological behavior of such tumors in female dogs are similar to breast carcinomas in women, for this reason female dogs present an excellent comparative model to understand various aspects of carcinogenesis in both species [6]. It is believed that mammary neoplasias may occur as a result of complex interactions of distinct factors; however the exact cause is still under research. Through this dynamic process, the mammary tumor can be influenced by internal host factors such as genetics and external factors, including environmental contamination, that can enable or reduce the individual response [7-9].

\footnotetext{
* Correspondence: rochanoeme@fmvz.unesp.br

${ }^{2}$ School of Veterinary Medicine and Animal Science, São Paulo State University
} (UNESP) - Botucatu, SP, Brazil
The pyrethroids are among environmental contaminants the ones whose use has exponentially grown in recent years [10]. They are used to control pests in agriculture, ranching and domestic animals. The overspread use of this contaminant is associated with its efficiency in pest control and its relatively short half-life [11-13]. In humans and other animals, pyrethroids are readily absorbed cutaneously and also in the digestive and respiratory tracts. Once absorbed they are distributed to various tissues, but they are concentrated especially in the adipose tissue. International Agency for Research Cancer (IARC) includes agrotoxins, especially deltamethrin and cypermethrin in group 3 of risk level, that is, non-conclusive carcinogenic for humans, while the World Health Organization (WHO) classifies deltamethrin as a moderately dangerous insecticide [14,15]. Considering that this research line is still not used in regular basis for the veterinary medicine, the present study aimed to detect and identify levels of pyrethroid

\section{Biomed Central}


insecticides in adipose tissue adjacent to malignant mammary tumor in female dogs by the HPLC method and correlate these contaminants with the aggressiveness degree of the neoplasias.

\section{Material and Methods}

Nine female dogs with mammary gland swelling (Fig. 1) were attended at the UNESP Veterinary Hospital in Botucatu, São Paulo - Brazil, and underwent mastectomy to excise the tumor (Fig. 2). Five grams of adipose tissue adjacent to the mammary tumor were analyzed by High Precision Liquid Chromatography - HPLC, following the Bissacot and Vassilieff method [16] (1997). Fragments of mammary tumor were fixed in $10 \%$ buffered formalin for $24 \mathrm{~h}$, and then they were dehydrated in alcohol, diaphanized in xylene and put into paraffin. They were then cut into $3 \mu \mathrm{m}$-width fragments and stained with Hematoxylin-Eosin (HE). For the analysis of tumors it was used the Veterinary [17] and Human [18] classification. Immunohistochemical analysis followed the protocols from the Immunohistochemistry Laboratory from the Department of Clinical Veterinary Medicine of the School of Veterinary Medicine and Animal Science - UNESP - Botucatu. Antigen retrieval was carried out by microwave treatment in a $10 \mathrm{mM}$ citrate buffer, $\mathrm{pH}$ 6.0. Tissue sections were incubated with primary monoclonal antibodies against ER (Novocastra UK), clone LH2, in 1:40 dilution, incubated for $120 \mathrm{~min}$ and developed with polymer Novolink (Novocastra, UK). Tumors were considered positive when they presented more than $10 \%$ of nuclear marks from marked neoplasic cells. Graduations were set according to the intensity of positive marking as follows: $(+)$ low intensity $(++)$ mild intensity and $(+++)$ high intensity described in previous studies [19].

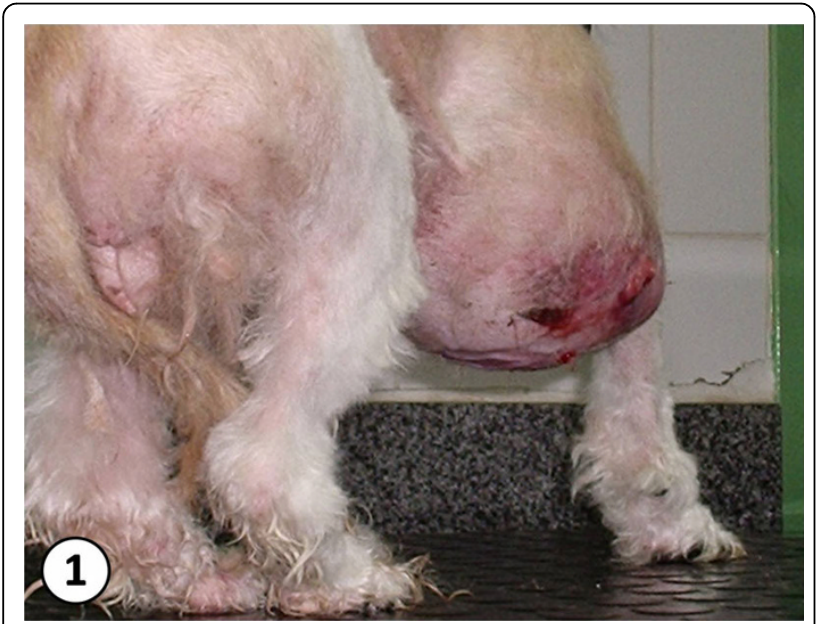

Figure 1 great increase in right cranial mammary gland.

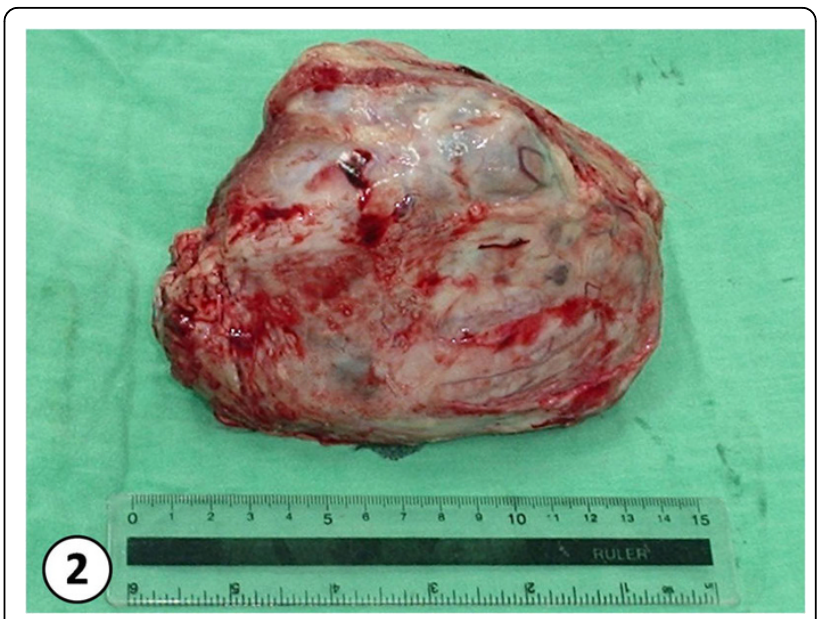

Figure 2 tumor after unilateral mastectomy

\section{Results}

According to the Veterinary classification, from the nine examined tumors, three (33.3\%) were classified as simple carcinoma (Fig. 3), and six (66.7\%) as complex carcinoma (Fig. 4). But when it comes to the Human Medicine classification these nine cases were divided into: three (33.3\%) simple carcinoma, being one tubulo-papilliferous, one ductal, one ductal infiltrative, and six (66.7\%) metaplasic carcinomas. As for the histological malignity two tumors were degree I $(22,2 \%)$ and seven tumors were degree III $(77,8 \%)$. Receptors marking were positive for 5 animals, regardless of their mark intensity. From 9 analyzed female dogs, pyrethroids were detected in three animals distributed in the following manner: one (11.1\%) female dog with $0.55 \mathrm{mg} / \mathrm{g}$ of deltamethrin and $0.32 \mathrm{mg} / \mathrm{g}$ of cyhalothrin; one (11.1\%) female dog

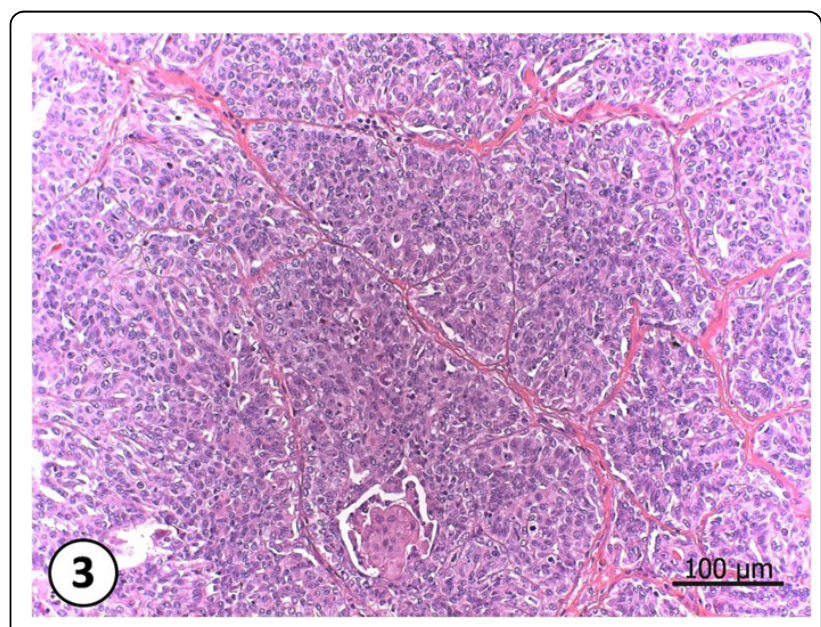

Figure 3 Simple Carcinoma. Neoplasia composed by proliferated epithelium cells, generating a hard standard with the loss of the glandular architecture. 


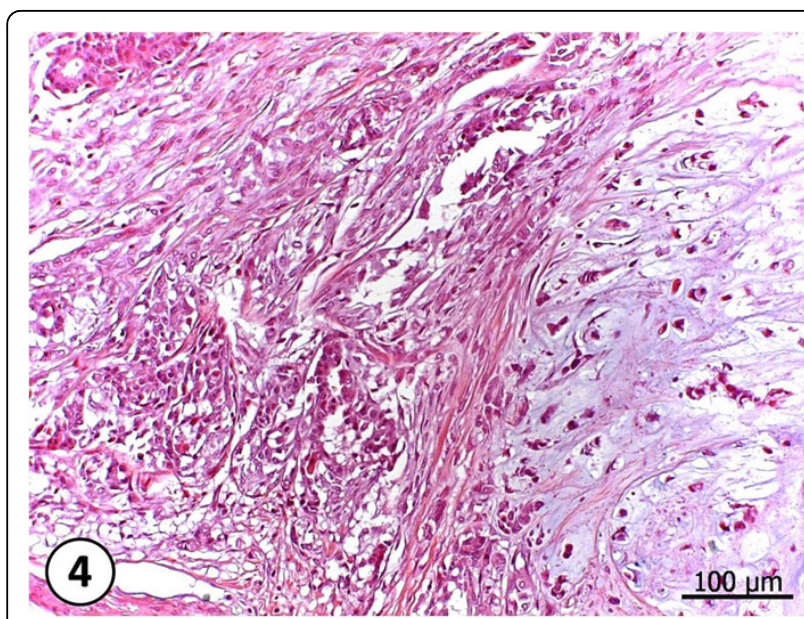

Figure 4 Complex carcinoma. Neoplasia composed by more than one cell type. Proliferated epithelial cells, with loss of gland architecture and presenting pleomorphism. Elongated mioeptithelial cells, presenting cartilagenous metaplasia and condroid matrix production. HE, 200X

with $0.02 \mathrm{mg} / \mathrm{g}$ of deltamethrin and $0.05 \mathrm{mg} / \mathrm{g}$ of allethrin and one (11.1\%) female dog with $0.03 \mathrm{mg} / \mathrm{g}$ of cypermethrin. Results are shown in table 1 and in the HPLC graphics (see Additional file 1).

\section{Discussion}

It is very little the number of studies connecting steroid hormone receptors and mammary tumors in female dogs. However, some human and canine carcinogenic hormone aspects seem to be similar. Toxicological and Epidemiological studies have shown that steroid hormones and synthetic derived trigger the development of

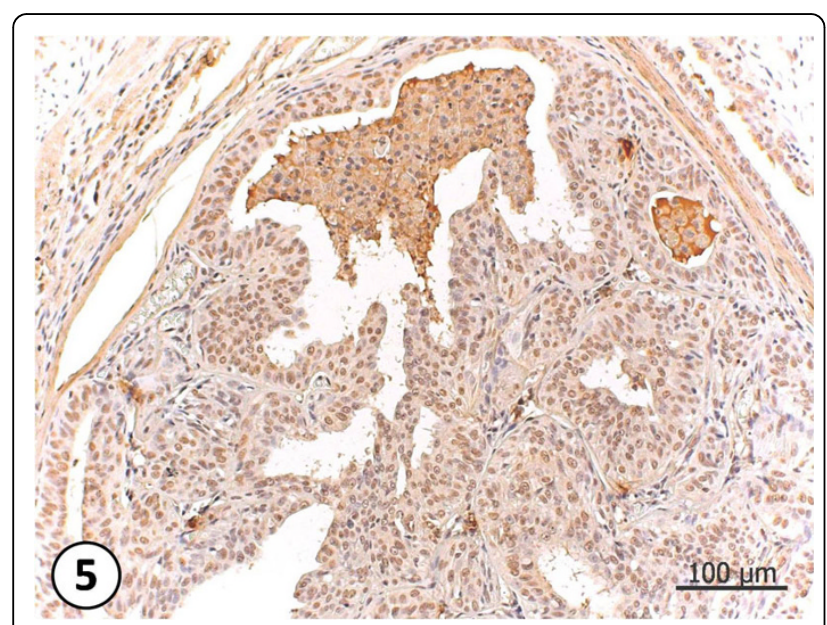

Figure 5 Estrogen receptors' Immunohistochemical picture. Observe the nuclear pattern marking. Simple carcinoma, grade III, + ++ for ER. 200X.

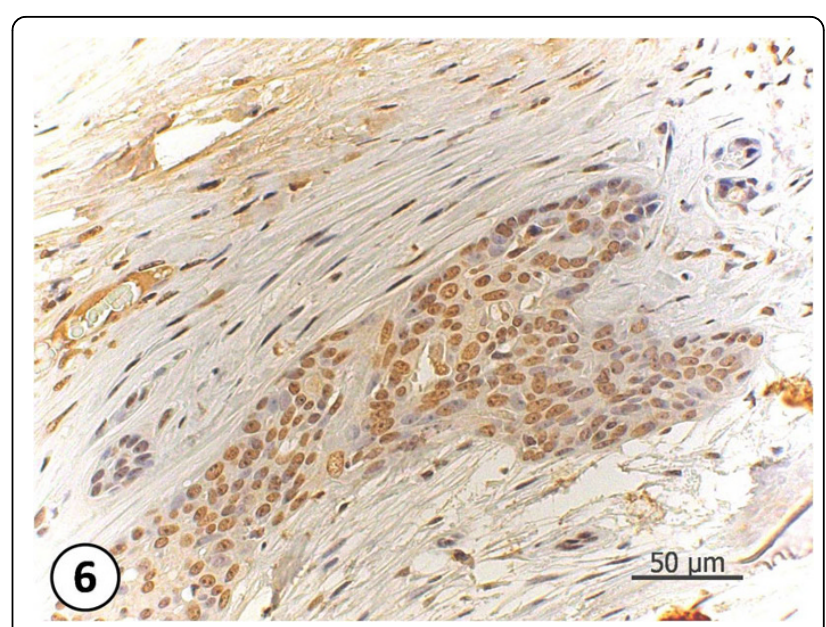

Figure 6 Estrogen receptors' Immunohistochemical picture. Complex carcinoma, grade III, +++ for ER. 400X.

mammary gland, suggesting that they may play an important role in the canine mammary tumor pathogenesis [20].

It is said that in the hormonal carcinogenesis, unlike the one induced by virus or chemical agents, the cell proliferation does not need a specific triggering agent. Hormones induce the cell proliferation together with genetic mutations that will give rise to neoplasic cells [21]. However, Carreño et al. (1999) [22], shows that the hormone role in the carcinogenesis is restricted to the proliferation of cells that have already been changed by other carcinogens. Specific genes involved in the development of hormone-dependent neoplasias are still unknown. Nevertheless, it is believed that oncogenes, genes that are tumor suppressors and the genes of DNA repairment are involved in the hormonal carcinogenesis, especially in the one induced by sexual steroids [23]. Having said that, this study has shown that the detected contaminants were present in more aggressive tumors (degree III and +++ for estrogen receptors- Fig.5 and 6). Even though the literature showing that being positive for estrogen receptors may result in good prognostic for women [24], the results from this preliminary study suggest that the presence of pyrehroids in the peritumoral fat may have triggered the local estrogenic effect and thus triggered higher proliferation of tumor cells. Scheme below (Fig. 7) shows the carcinogenesis of mammary tumor and the role of pyrethroids in the proliferation of tumors.

Epidemiological studies and tests on rodents have demonstrated the influence of environmental contaminants on neoplasia development, including breast cancer $[10,25,26]$. Garey et al, (1998) [27] emphasized that pyrethroids can induce a breakdown in the homeostasis of hormones such as estrogens and indirectly influence cell 


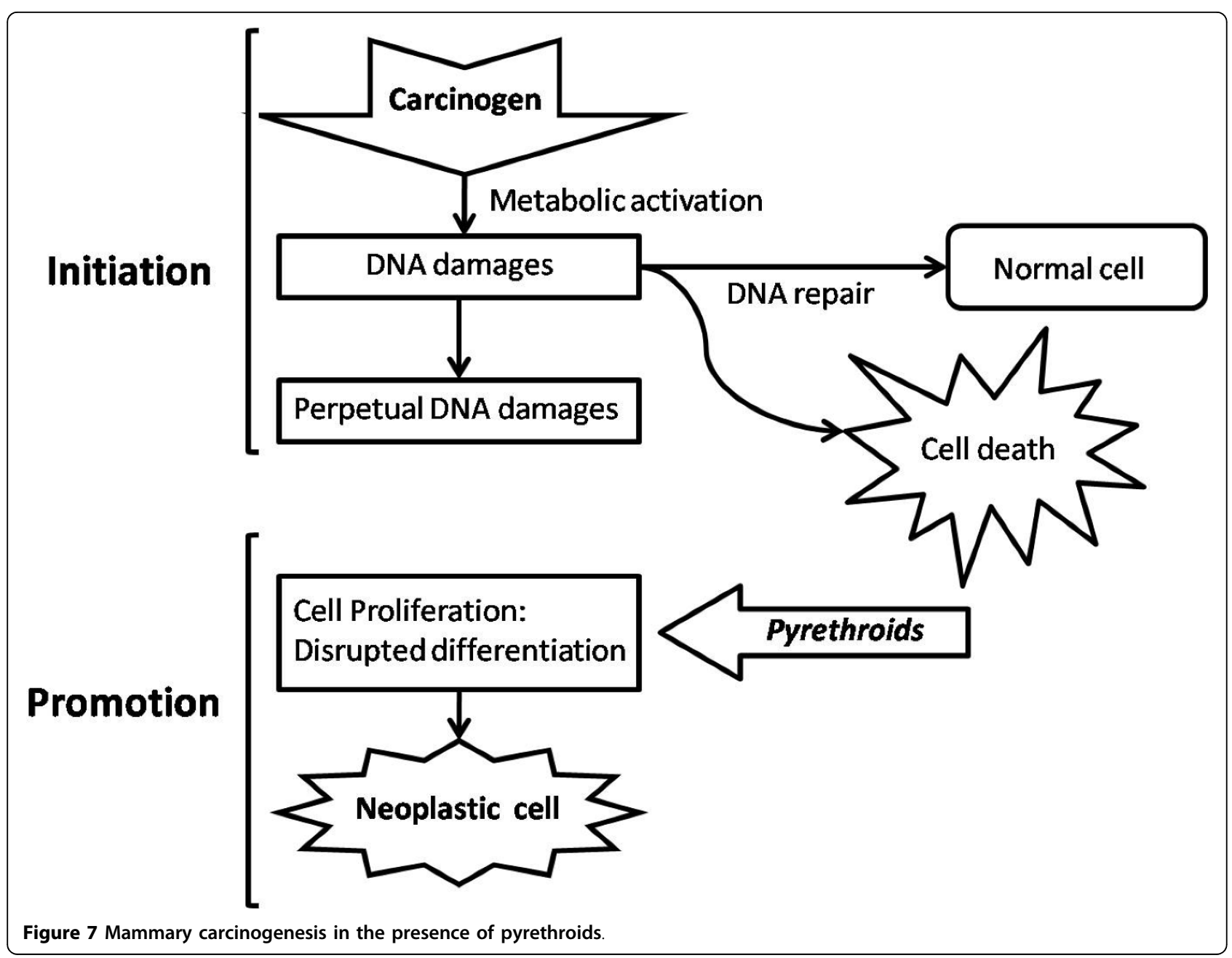

Table 1 Veterinary and Human histopathological classification of Malignant mammary tumor in female dogs showing their malignity, positive immunemarking for estrogen receptors, and pyrethroid identification with their respective concentration levels in the analyzed samples

\begin{tabular}{|c|c|c|c|c|c|}
\hline \multicolumn{2}{|c|}{ Classification - Carcinoma } & \multirow[t]{2}{*}{ Degree } & \multirow[t]{2}{*}{ Estrogen Receptor } & \multicolumn{2}{|r|}{ HPLC } \\
\hline Veterinary & Human & & & $\mu \mathrm{g} / \mathrm{g}$ & Pyrethroid \\
\hline Simple & Tubulo-papilliferous & III & +++ & 0.550 .32 & Deltamethrin Cyhalothrin \\
\hline Complex & Metaplasic & 1 & 0 & & --- \\
\hline Complex & Metaplasic & III & +++ & 0.050 .02 & Allethrin Deltamethrin \\
\hline Complex & Metaplasic & III & 0 & & \\
\hline Simple & Ductal & I & ++ & & - \\
\hline Simple & Ductal infiltrative & III & + & & - \\
\hline Complex & Metaplasic & III & +++ & 0.03 & Cypermethrin \\
\hline Complex & Metaplasic & III & 0 & & - - \\
\hline Complex & Metaplasic & III & 0 & & -———- \\
\hline
\end{tabular}

proliferation or apoptosis, either increasing or diminishing them in mammary epithelial cells, thereby triggering the neoplastic process. Results obtained in the present study detected the presence of $33.3 \%$ of pyrethroid pesticides in adipose tissue of female dogs with mammary carcinoma.

In order to improve results, and collection of data, our group is still researching such environmental 
contamination, increasing the number of samples as well as including samples from control animals.

\section{Additional material}

Additional file 1: Standard for HPLC of pyrethroids and adipose tissue with pyrethroid contamination. Graphics presenting the standard data for HPLC of pyrethroids and adipose tissue with pyrethroid contamination.

\section{Acknowledgements}

We acknowledge CAPES and FAPESP (2008/57.309-5) for the financial support.

\section{Author details}

${ }^{1}$ Maranhão State University (UEMA), São Luis, MA, Brazil. ${ }^{2}$ School of Veterinary Medicine and Animal Science, São Paulo State University (UNESP) - Botucatu, SP, Brazil. ${ }^{3}$ CEATOX - Botucatu Bioscience Institute (UNESP) - Botucatu, SP, Brazil.

\section{Authors' contributions}

FHEA have made substantial contributions to the conception, design and collection of samples. FCF have made substantial contributions to the conception, design, interpretation of histopathological and immunohistochemical data, and critically revising it for important intellectual content. PROB have been involved in drafting the manuscript, tables, schemes and critically revising it for important intellectual content. DZB carried out the HPLC quantification and the interpretation of data. NSR conceived the study, and participated in its design and coordination, and also helped to draft the manuscript. All authors read and approved the final version of the manuscript.

\section{Competing interests}

The authors declare that they have no competing interests.

Received: 8 October 2009 Accepted: 30 June 2010

Published: 30 June 2010

\section{References}

1. Daleck CR, Franceschini PH, Alessi AC, Santana AE, Martins MIM: Aspectos clínico e cirúrgico do tumor mamário canino. Ciência Rural 1998, 28:95-100.

2. Oliveira LO, Oliveira RT, Loretti A, Rodrigues R, Driemeier D: Aspectos epidemiológicos da neoplasia mamária canina. Act Sci Vet 2003, 31:105-110.

3. Fonseca CS, Daleck CR: Neoplasias mamárias em cadelas: influência hormonal e efeitos da ovariohisterectomia como terapia adjuvante. Ciência Rural 2000, 30:731-735.

4. Gilbertson SR, Kurzman ID, Zachrau RE, Hurvitz Al, Black MM: Canine mammary epithelial neoplasms: biological implications of morphological characteristics assessed in 232 dogs. Vet Pathology 1983, 20:127-142.

5. Sorenmo K: An update on canine mammary gland tumors. ACVIM Forum 16 1998, 387-388, Proceedings.

6. Peleteiro MC: Tumores mamários na cadela e na gata. Revista Portuguesa de Ciências Veterinárias 1994, 89:10-29.

7. Nerurkar VR, Chitale AR, Jalnapurkar BV, Naik SN, Lalitha VS: Comparative pathology off canine mammary tumors. J Comp Pathology 1989, 101:88-397.

8. O'Brien DJ: Spatial and temporal comparison of selected cancers in dogs and humans. Prev Vet Med Michigan, USA 2000, 47:187-204, 1964-1994.

9. Schneider R, Dorn CR, Taylor DON: Factors influencing canine mammary cancer development and postsurgical survival. Journal of the National Cancer Institute 1969, 43:1249-61.

10. Instituto Nacional de Câncer (INCA): Estimativa para 2005 da incidência e mortalidade por câncer no Brasil. Ministério da Saúde Rio de Janeiro 2006.

11. Goulart SM, Queiroz MELR, Neves AA, Queiroz JH, Alves IC: Anais da $27^{\circ}$ Reunião Anual da SBQ e $26^{\circ}$ Congresso Latino Americano de Química. Salvador 2004.
12. Organización Mundial de la Salud: Resistencia de vectores y reservorios de enfermedades a los plaguicidas: Comité de expertos en Insecticidas. $22^{\circ}$ Informe, WHO Serie n. ${ }^{\circ} 585$ Ginebra: WHO 1976.

13. Wright JW: The WHO program for the evaluation and testing of new insecticides. Bull WId Hith Org 1971, 44:11-2.

14. International Agency For Research Cancer - IARC: Overall evaluations of carcinogenicity to humans. IARC Lyon 1987 [http://monographs.iarc.fr/ ENG/Monographs/vol53/mono53-10.pdf], (2005).

15. Environmental Protection Agency: Pyrethrins: Report of the Cancer Assessment Review Committee. Third Evaluation. EPA 2004 [http://www. cepis.ops-oms.org/bvsacd/cd49/pesticide.pdf].

16. Bissacot DZ, Vassilieff I: HPLC determination of flumethrin, deltamethrin cypermethrin and cyhalothrin residues in milk and blood of lactating dairy cows. Jour Anal Toxic 21:397-402, 199.

17. Misdorp W, Else RW, Hellman E, Lipscomb TP: Histological classification of mammary tumors of the dog and the cat. Armed Forces Institute of Pathology Washington 1999, 7:58.

18. Rosen PP, Oberman HA: Tumors of mammary gland. Armed Forces Institute of Pathology Washington 1993, p390.

19. Schmitt FC, Bento MJ, Amendoeira I: Estimation of estrogen receptor content in fine-needle aspirates from breast cancer using the monoclonal antibody 1D5 and microwave oven processing: correlation with paraffin embedded and frozen sections determinations. Diagn Cytopathol 1995, 13:347-351.

20. Rutterman GR, Misdorp W: Hormonal background of canine and feline mammary tumors. J Reprod Fert Supp/ 1993, 47:483-487.

21. Donney I, Rauis J, Wouters-Ballman P, Devleeschouwer N, Leclerq G, Verteegen JP: Receptors for estrogen, progesterone and epidermal growth factors in normal and timorous canine mammary tissue. J Reprod Fert, Supp/ 1993, 47:501-512.

22. Carreño MSR, Peixoto S, Giglio A: Reposição hormonal e câncer de mama. Rev Soc Bras Canc 1999, 7:41-50.

23. Henderson BE, Feigelson HS: Hormonal carcinogenesis. Carcinogenesis 2000, 21:427-433.

24. Silva $A E$, Serakides $R$, Cassali GD: Carcinogênese hormonal e neoplasias hormônio-dependentes. Ciência Rural 2004, 34:625-633.

25. Amorim LMFA, Rossini A, Mendona GAS, Lotsch PF, Simo TA, Gallo CVA, Pinto LFR: CYP1A1, GSTM1, and GSTT1 polymorphisms and breast cancer risk in Brazilian women. Cancer Lett 2002, 181:179-186.

26. Environmental Protection Agency - EPA: Health Effect Division. Office of Pesticide Programs. Chemicals Evaluated for Carcinogenic Potential. Informative 2006, 49

27. Garey J, Wolff M: Estrogenic and antiprogestagenic activities of pyrethroid insecticides. Biochem Biophys Res Commun 1998, 251:855-859.

doi:10.1186/1746-1596-5-45

Cite this article as: Andrade et al:: Malignant mammary tumor in female dogs: environmental contaminants. Diagnostic Pathology 2010 5:45.

\section{Submit your next manuscript to BioMed Central and take full advantage of:}

- Convenient online submission

- Thorough peer review

- No space constraints or color figure charges

- Immediate publication on acceptance

- Inclusion in PubMed, CAS, Scopus and Google Scholar

- Research which is freely available for redistribution
C Biomed Central 